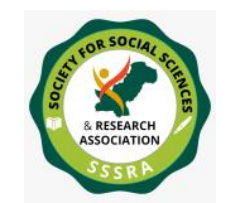

Pak. Journal of Int'L Affairs, Vol 4, Issue 4 (2021) Future Prospects of Pakistan China Relations ...

\title{
FUTURE PROSPECTS OF PAKISTAN CHINA RELATIONS: A CASE STUDY OF CHINA-PAKISTAN ECONOMIC CORRIDOR (CPEC)
}

\author{
Dr. Nighat Firdous \\ School of Marxism \\ Yangzhou University \\ Jiangsu - China \\ nighatfirdous777@yahoo.com \\ Junaid Ahmad Zia \\ Master in Business Administration \\ School of Economics and Management \\ Shihezi University \\ Xinjiang - China \\ junaidmastuj@gmail.com \\ Muhammad Asghar Khan \\ School of Economics and Management \\ Panzhihua University \\ Panzhihua-China \\ asgharkhan@pzhu.edu.cn
}

\section{Abstract}

China Pakistan Economic Corridor (CPEC) provides benefits opportunities for Pakistan and China. This project is a framework of a multi-dimensional project that will help Pakistan's infrastructure in different fields. However, both countries desire to build the CPEC project with enthusiasm which is part of OBOR. CPEC greatly influences the global economy by incorporating a huge part of the world under an umbrella to reconnect China with the Middle East, Africa, and European countries (from China's Xinjiang region to Pakistan port Gwadar). We investigated to overview the significance of the CPEC however, a questionnaire survey was collected a lot of basic data. Approximately a section of 1000 different respondents had selected with the help of a multistage sampling method from all of Pakistan. A questionnaire analysis was collected primary data. The questionnaire survey results were the prospects of Pakistan and China under the CPEC project. Furthermore, Prospective the CPEC project will provide tourism, education and cultural 


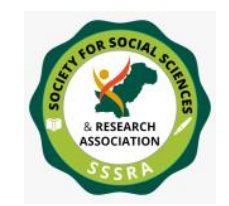

Pak. Journal of Int'L Affairs, Vol 4, Issue 4 (2021) Future Prospects of Pakistan China Relations ...

programs opportunities in the different fields for the development of both countries. The participant of the survey of the people proves that the CPEC will be accommodating and achieve the goals which are the target in the future.

Keywords: OBOR, Prospects of Pakistan and China from CPEC, Education and culture program

\section{Introduction}

The targets of the CPEC project are to the foundation of the energy, transportation framework, and Gwadar port, which assume a huge part in expanding the nation's economy. CPEC will be the destiny and distinct advantage of Pakistan for its particular economies and provincial network and will increase a common new development. It is a confident and most welcomed project that brought financial prospering to Pakistan (Ibrar, 2018). Notwithstanding, China's President Xi Jinping announced two revelations in September and October 2013, individually. The originally was made in Kazakhstan, where he declared the 'Silk Road Economic Belt and the subsequent declaration was ready in Indonesia, where he reported the 'Oceanic Silk Road'. Together, these are both known as 'One Belt One Road (OBOR) (Bhoothalingam, 2016). OBOR is the rebuilding of the old Silk Road, yet it tremendously influences the overall economy by joining a gigantic piece of the world under an umbrella. It expands its chances through worked on recorded infrastructural headway. It connects the world with people through political, monetary, and social correspondences (Uberoi, 2016). President Xi best summarizes the BRI: "China will successfully progress worldwide co-action through the Belt and Road Initiative. In doing all things considered, we want to achieve the technique, framework, trade, money related, and individuals to-individuals network and along these lines fabricate another stage for worldwide participation to make new drivers of shared improvement" (Jinping, 2017). Xi's system was not commonly new yet rather dependent on Chinese abroad establishment improvement practices pursued over the past 25 years. The included distinctive energy, transportation, and different undertakings, generally in Central and Southeast Asia (Kalathil, 2017). The Idea of OBOR has a fundamental worldwide importance. The OBOR drive covers nations and areas with an entire populace of 4.4 billion and incorporates an absolute financial volume of US\$ 21 trillion, $63 \%$ and $29 \%$ correspondingly of the world's total (Liping, 2015). Altogether, OBOR will relate 65 nations covering 33\% of overall yield, $40 \%$ of worldwide exchange and $62 \%$ of the overall populace (Ramasamy, 2017). 

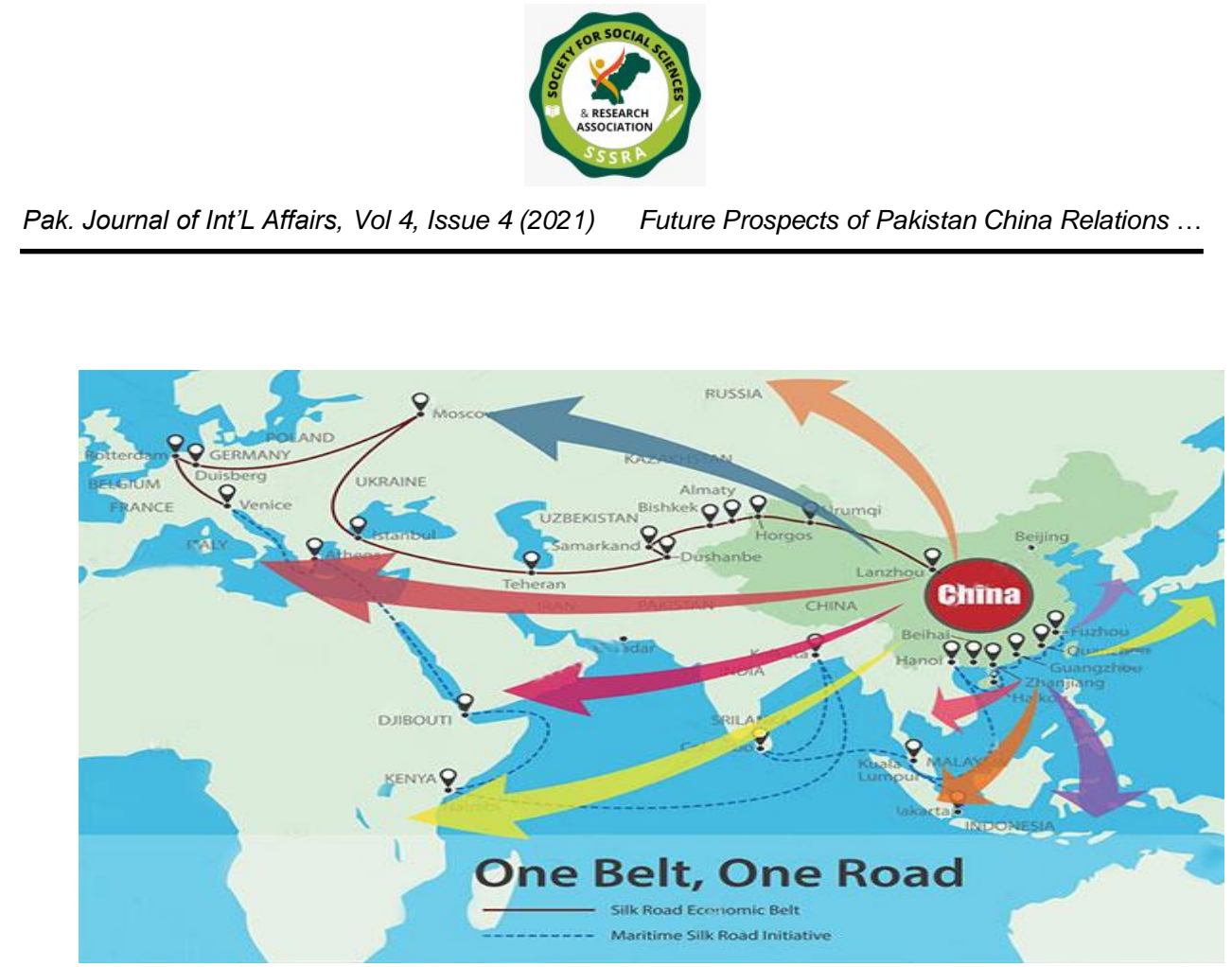

Figure 1 : Map of One Belt One Road

https://www.topchinatravel.com/silk-road/one-belt-one-road.htm

The fundamental point of the Belt and Road drive is to upgrade the B\&R drive countries' financial success by improving the transport groundwork. As OBOR is a connection of land and sea routes, which will link Sub-regions in Asia, Europe, and Africa, counties besides OBOR will work on their framework and development drives by keeping in the security and sway of all economies. Also, a foundation will be created which will work with the global transport of various regions; Railways and highways; seaports, Aviation, Energy and gas pipelines, power supply and, Communications-Optical networks (Abid, 2015). These corridors will comprise networks of rail routes, roads, waterways, pipelines and information highways that connect industrial and energy clusters and contain both overland and a maritime component. Likewise, the BRI comprises two global and an inside, relating individually to foundation projects attempted with neighbouring countries and those embraced inside China's inside districts (Das, 2017).

\section{Under OBOR Six Economic Corridors}

OBOR have overall Six Economic Corridors Spanning Asia, Europe and Africa, six corridors and one maritime Silk Road (Sarker, 2018) 

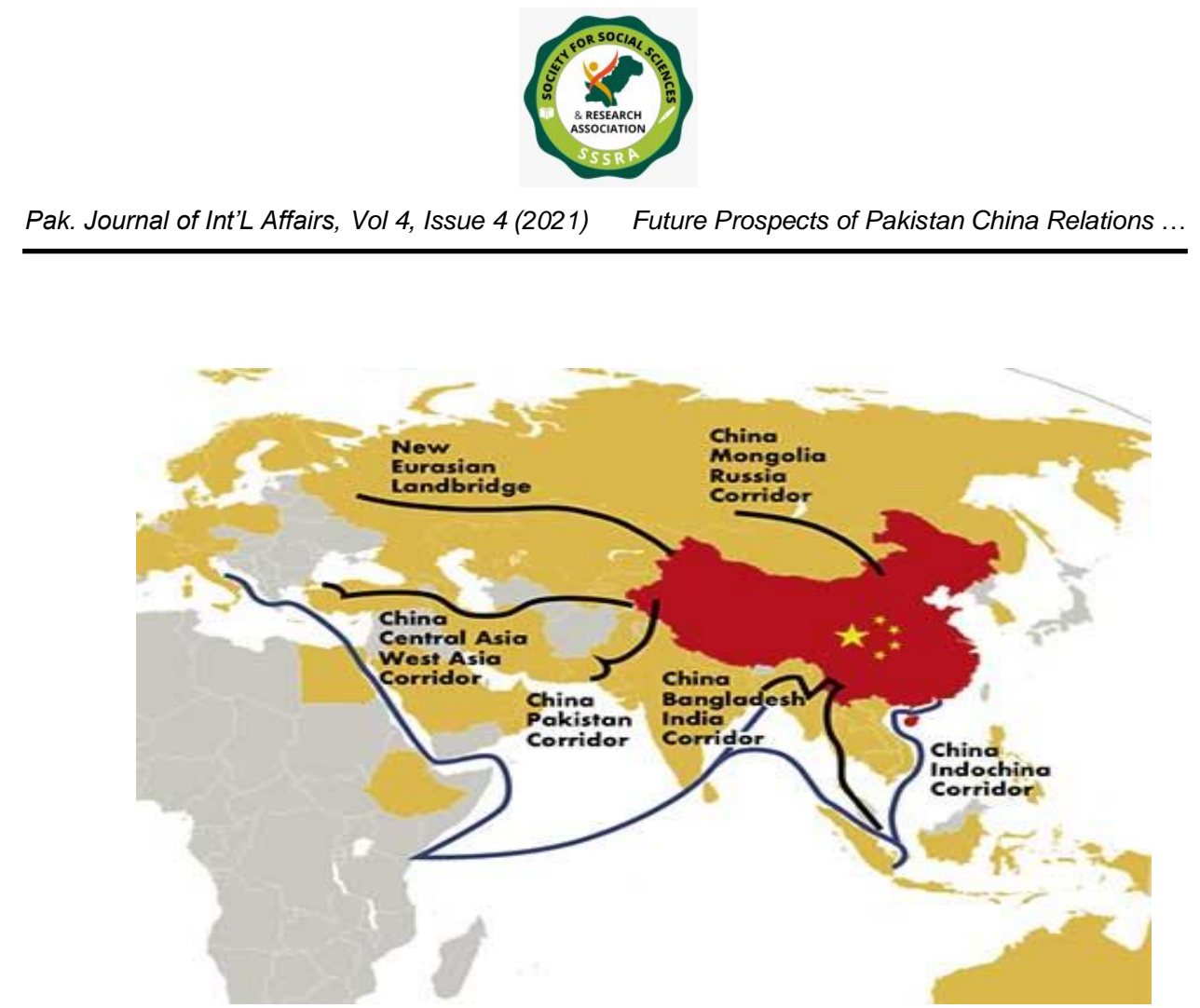

Figure 2 : Six Economic Corridor under the One Belt One Road

\section{Background of China-Pakistan Relations}

In 1951 formal discretionary relations were set up among Pakistan and China. Pakistan was the main Muslim and third non-socialist Country to fabricate discretionary relations with China (Bhola, 1986). After China and Pakistan set up their boundary question, they agreed to their first exchange deal 1963. Starting around 1969, also, the two nations have denoted a yearly line exchange settlement managing trades between Pakistan's Northern and China's Xinjiang locale (Vertzberger, 1983).

Further, the expressway is the Pakistan-China Friendship Highway and is continually loosening up for transportation between the two nations (Ali, 2015). The CPEC is an umbrella projected as a piece of the OBOR (Markey, 2016). The errand under the CPEC is the Gwadar Port, and its appropriateness for financial of Pakistan. In any case, Gwadar with respect to its extended financial and political presence in the West Asia, Europe, and African districts (U1 Hassan, 2020).

\section{Significance of China-Pakistan Economic Corridor under (OBOR)}

OBOR states can gain from the experiences of the CPEC to augment the upside of venture among different vehicle frameworks. The advancement of CPEC is one of the super undertakings under BRI and Pakistan is a basic pal country in the execution of the Belt and Road Initiatives (Masood, 2015). After the China Pakistan Economic Corridor, Pakistan 


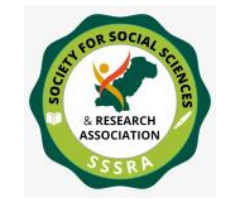

Pak. Journal of Int'L Affairs, Vol 4, Issue 4 (2021) Future Prospects of Pakistan China Relations ...

monetary improvement has fundamental worth in the area since Pakistan is a non-industrial nation. Be that as it may, later on, Gwadar port will transform into a financial heart of the world (Malik, 2012). The OBOR land courses associate up with other street and rail plans (organized or under execution) which interface China to its bordering areas, for instance, the CPEC (driving from China's Xinjiang locale to the Pakistani port of Gwadar) (Bhattacharjee, 2015). CPEC likes full assistance from both the Chinese and Pakistani state run administrations and individuals of the two nations. It was the principle part of "One Road and One Belt", to which China annexes remarkable importance (Rehman, 2018). CPEC is a huge essential issue through which China may associate the sub-landmass, Central Asia and Africa and make benefits for around 3 billion people in this enormous district. "One Belt and One Road" is China's public system, and CPEC is the Belt and Road Initiative (Alexandrova, 2009).

\section{Initiative of CPEC Project}

The CPEC is the flagship of China's OBOR drive imagined by Chinese president $\mathrm{Xi}$, in 2013 for the economic integration of Eurasia concluded belts and roads and other structures initiatives (Akber, 2015). Moreover, President Xi Jinping situated that the two countries locations need to respect CPEC creation because the core of the task, with the Gwadar Port, transportation infrastructure, forming a $1+4$ helpful configuration. The countries may, in this manner, utilization understanding mutually beneficial participation and normal improvement and advantage from a significant demonstration of interconnections (Yun, 2015). The core purpose of CPEC is that energy sectors' capability of development in the country simultaneously, on this task, 33.99 billion has reserved for the energy sectors. As a part of CPEC, around 22 energy projects will be set up inside the essential portion of produced funds via China. Since the energy projects are of various potential and kinds, policy-makers expect to choose where to introduce this verdure, Yet starting in 2017, and its value has expanded to $\$ 62$ billion (Siddiqui, 2017). Under China CPEC, China decided to invest US $\$ 46$ billion in the development project, approximately 20 per cent of Pakistan's annual GDP (Stevens, 2015).

\begin{tabular}{ccc}
\hline Projects & Cost (Million USD) \\
\hline Energy Sector & 33,728 & \\
Infrastructure and transportation Development & 11,636 \\
Gwadar Port Development & 792.6 \\
Others (Option Fiber) & 44 \\
Total & $46,200.6$ \\
\hline
\end{tabular}

Table 1 Project Apportionment (Rafiq, 2016). 


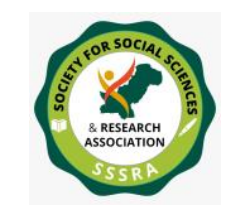

Pak. Journal of Int'L Affairs, Vol 4, Issue 4 (2021) Future Prospects of Pakistan China Relations ...

CPEC is an assignment that interfaces the decisively basic city of Gawadar in Pakistan's Balochistan area with the city of Kashgar in China's Xinjiang district (Ahmad, 2017).

\section{Materials and Methods}

The present research study was based on the survey respondents of all of the Pakistani people. There is the basic topic of the CPEC project, which significant role in the development of Pakistan. A sample of a total of 1000 respondents was chosen from the country through a multistage sampling technique. The samples were taken by using a multistage sampling technique.

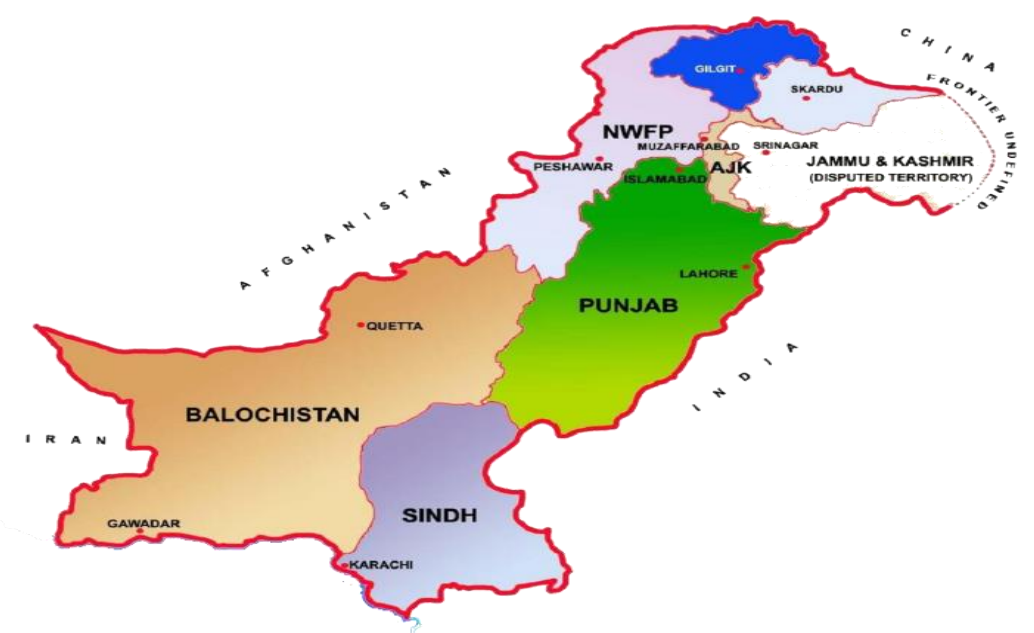

Figure 3: Map of Pakistan

\section{Data Collection Tool Survey}

For this research, a questionnaire was used as a tool for data collection essential for the survey. The survey tool we have used to collect data from the different peoples is both open-ended and close-ended questions. Our survey questionnaire was all of the Pakistani people's options according to the variables. The survey respondents were livings in different scattered regions of the country. The selection technique used for the study is simple random sampling. This methodology offers appropriate information data to gather information about the populace, and it is easy to utilize because it represents the whole populace, and each individual has an equivalent option to participate (Khalid, 2015).

\section{Research Points of Study}




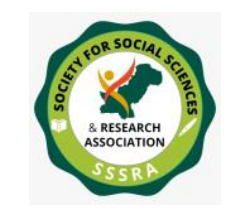

Pak. Journal of Int'L Affairs, Vol 4, Issue 4 (2021) Future Prospects of Pakistan China Relations ...

Hypothetically, this study focused on defining the following research objectives.

$>$ To assess the importance of CPEC observation of the public opinion of Pakistani people.

$>$ To analyses the prospects under the CPEC project to the Pakistan and China benefits, and highlight accounting to the public opinion.

\section{Results of Univariate Analysis}

\section{Prospects of Pakistan from CPEC Project}

Table 2 articulations that $21.0 \%$ of the respondents had data that CPEC is a financial venture, $17.5 \%$ of them told that CPEC is an energy project, $21.4 \%$ of them had data that CPEC is a transportation networks project (rail line and street) project, $14.5 \%$ of them told that CPEC is a Gwadar port advancement undertaking and $25.6 \%$ of the respondents had imagined that CPEC is a task which had all above discussed kinds of task. Albeit, the fundamental central drives of CPEC will incorporate the energy area, transport foundation, optical fiber, pipelines, Gwadar Port, and the production of special economic zones (SEZs). In this condition, have an excellent chance for the improvement of Pakistan because the CPEC task will improve Pakistan's progress, and the country's conditions will improve in the future. The energy shortage in Pakistan is predicted to decrease probably via this megaproject because it's predicted that CPEC will allow the country to minimize electricity shortage to zero. According to Sun Weidong, Ambassador of China in Pakistan, "construction of infrastructure, transportation, industrial and energy tasks under CPEC projects will benefit socio-economic development across Pakistan in all provinces. CPEC is to build a road and a systematic plan to improve a network of roads, railways, and industries."

Table 2: Respondents' information about which type of project is included in the ChinaPakistan Economic Corridor (CPEC) project?

\begin{tabular}{lcc}
\hline Type of Projects & Frequency & Percentage \\
\hline Economic project & 210 & 21.0 \\
Energy project & 175 & 17.5 \\
Transportation networks project & 214 & 21.4 \\
Gwadar port project & 145 & 14.5 \\
All project & 256 & 25.6 \\
Total & 1000 & 100.0 \\
\hline
\end{tabular}


Pak. Journal of Int'L Affairs, Vol 4, Issue 4 (2021) Future Prospects of Pakistan China Relations ...

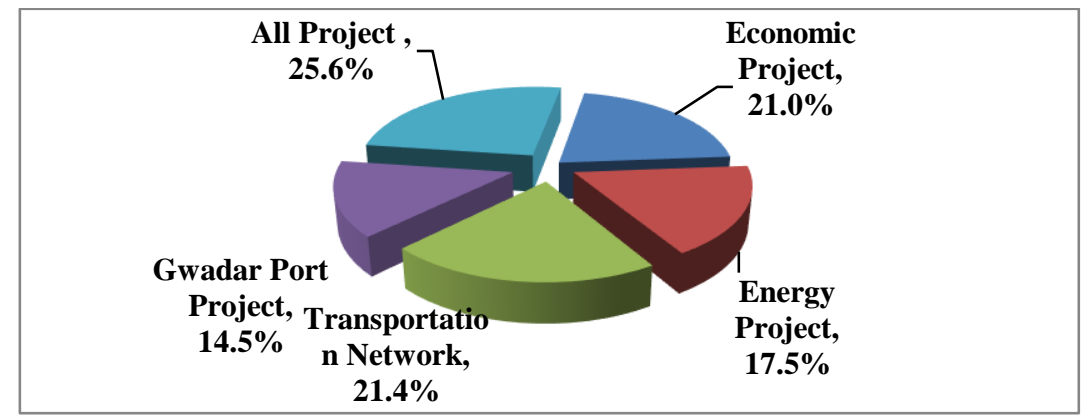

Figure 4. CPEC type of project

\section{CPEC Increase the Economy of Pakistan}

Table 3 uncovered that a colossal greater part, $80 \%$ of the respondents, revealed that CPEC works on the economy of Pakistan, albeit $9 \%$ of respondents had answered contrarily, and $11 \%$ of the respondents said that they didn't realize CPEC work on the economy of Pakistan. Financing in the CPEC project, China not just considers its have momentary monetary advantages yet, more significantly, minds around the drawn out essential need of Pakistani financial improvement (Xiguang, 2015). Up to this point, 70,000 Pakistanis have won work in CPEC projects (Achakzai, 2018). Another side, Pakistan's economy is projected to grow effectively, in a humble 5\% assortment, in every one of the following not many monetary years, buttressed through developing homegrown interest and a rising administrations area. Figuring in CPEC ventures, the World Bank expects the GDP rate to increase to $5.5 \%$ by 2018 and $5.8 \%$ in 2019 (Raza, 2013).

Table 3 Respondent's opinion that the infrastructure of the CPEC projects will improve the economy of Pakistan

\begin{tabular}{ccc}
\hline Response & Frequency & Percentage \\
\hline Yes & 800 & 80 \\
No & 90 & 9 \\
Don't Know & 110 & 11 \\
Total & 1000 & 100.0 \\
\hline
\end{tabular}




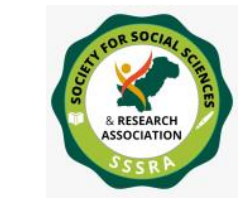

Pak. Journal of Int'L Affairs, Vol 4, Issue 4 (2021) Future Prospects of Pakistan China Relations ...

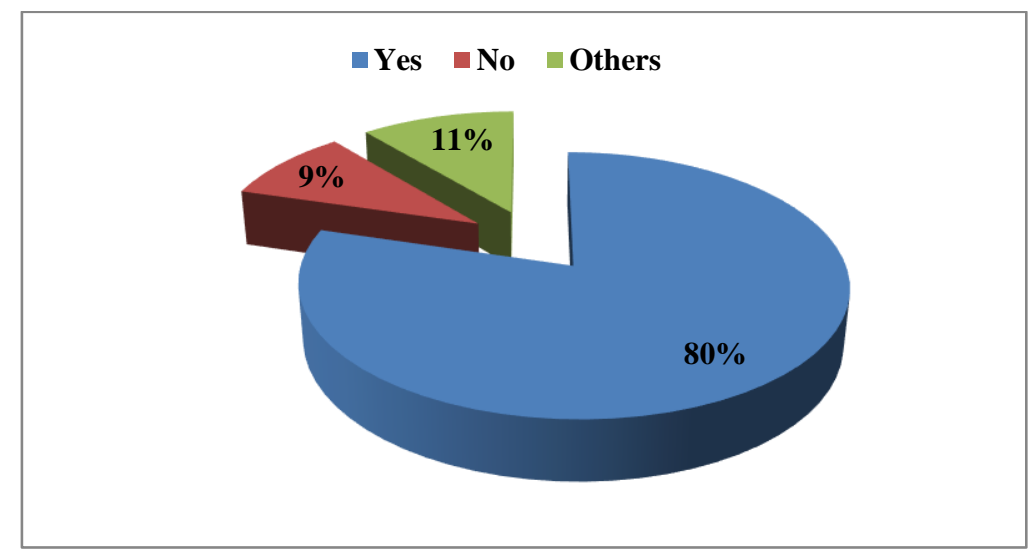

Figure 5. Knowledge about CPEC improve the economy of Pakistan

\section{CPEC Improve GDP Growth of Pakistan}

Table 4 demonstrates that $19.7 \%$ of the respondents had data that CPEC is a further develop GDP development, $19.0 \%$ of them said that CPEC is to further develop foundation progress, $12.7 \%$ of them had data that CPEC is to further develop an energy emergency, $14.4 \%$ of them said that CPEC is to work on friendly turn of events, $13.2 \%$ of them said that CPEC is to further develop FDI development and $21.0 \%$ of the respondents had imagined that CPEC is a task which had all above talked about CPEC work on various sorts of activities which are fundamental for the advancement of the country (Ramay, 2016). CPEC would upgrade business development and might interface business ventures of Pakistan universally, which could acquire families' social government assistance. These overall linkages would bring about more FDIs and exorbitant monetary development for China and Pakistan (Naz, 2018).

Further, viewed that as around $60.0 \%$ individuals of Pakistan have a place with the 30 years age gathering, and they don't have business and stress roughly what's to come. The undertaking under the CPEC, like transportation, exchange, and development, can make large number of new position possibilities for the jobless individuals of Pakistan. When the CPEC is functional, business and monetary zones on the passage course will likewise deliver new work open doors (Mughal, 2016). 
Pak. Journal of Int'L Affairs, Vol 4, Issue 4 (2021) Future Prospects of Pakistan China Relations ...

Table 4: Respondents' information about Why CPEC needs Pakistan.

\begin{tabular}{ccc}
\hline Why is CPEC necessary in Pakistan? & Frequency & Percentage \\
\hline Improve GDP growth & 197 & 19.7 \\
Infrastructure progress & 190 & 19.0 \\
Improve Energy crisis & 127 & 12.7 \\
Improve Social-Development & 144 & 14.4 \\
Improve FDI growth & 132 & 13.2 \\
All of these & 210 & 21.0 \\
Total & 1000 & 100.0
\end{tabular}

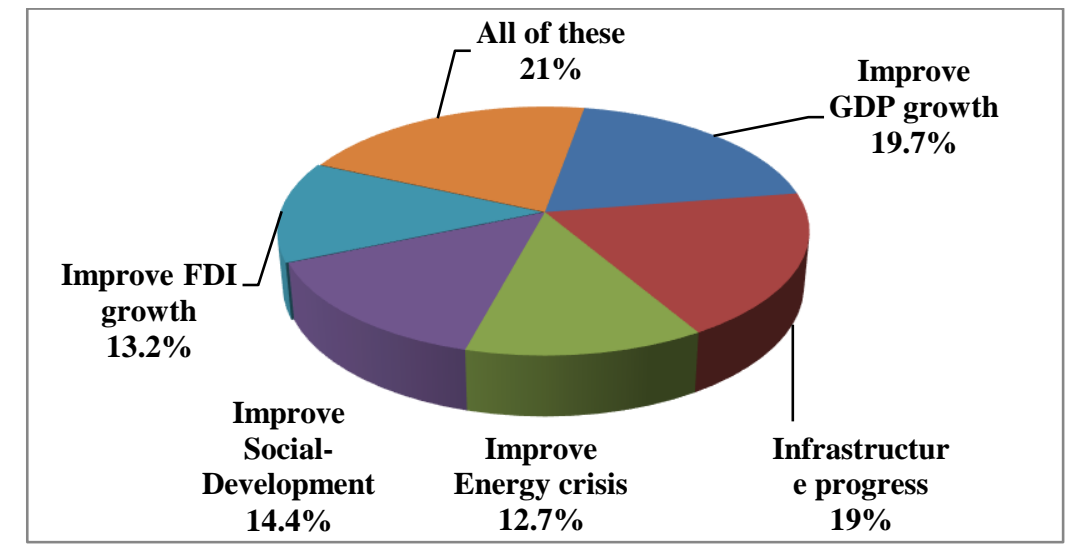

Figure 6. Information about the CPEC necessary's Pakistan

\section{CPEC Improve the Sectors of Pakistan}

Table 5 suggests that $15.3 \%$ of the respondents had information that CPEC is an improved agriculture sector, $21.2 \%$ of them said that CPEC is to improve an industry sector, $26.5 \%$ of them had information that CPEC is to improve the business sector, $14.8 \%$ of them said that CPEC is improve manufacturing sector, $18.9 \%$ of them said that all above these discussed that improve agriculture, Industry, Business, Manufacturing sector, and $3.3 \%$ of the respondents had not responded that CPEC would improve the sectors of Pakistan in the future. Pakistan is a non-industrial nation, and the CPEC project is a wide-going arrangement of steady ventures and drives, which covers primary regions, including availability, modern parks and enterprises, agrarian turn of events, data network foundation, availability, energy collaboration, the travel industry, destitution lightening, occupation improvement including civil framework just as monetary participation, general wellbeing, instruction, and individuals to-individuals contacts by connecting Kashgar with 
Future Prospects of Pakistan China Relations ...

Gwadar through Gilgit-Baltistan and different areas of Pakistan (Kaleem, 2019). The agricultural improvement procedure has been defined as a procedure to promote agricultural activities with agricultural technologies. It affects in better employment of agricultural resources (Akber, 2015).

Table 5: Respondent's information that CPEC will improve the sectors of Pakistan in the future

\begin{tabular}{ccc}
\hline Response & Frequency & Percentage \\
\hline Improve agriculture sector & 153 & 15.3 \\
Improve Industry sector & 212 & 21.2 \\
Improve Business sector & 265 & 26.5 \\
Improve Manufacturing sector & 148 & 14.8 \\
All of these & 189 & 18.9 \\
None & 33 & 3.3 \\
Total & 1000 & 100.0 \\
\hline
\end{tabular}

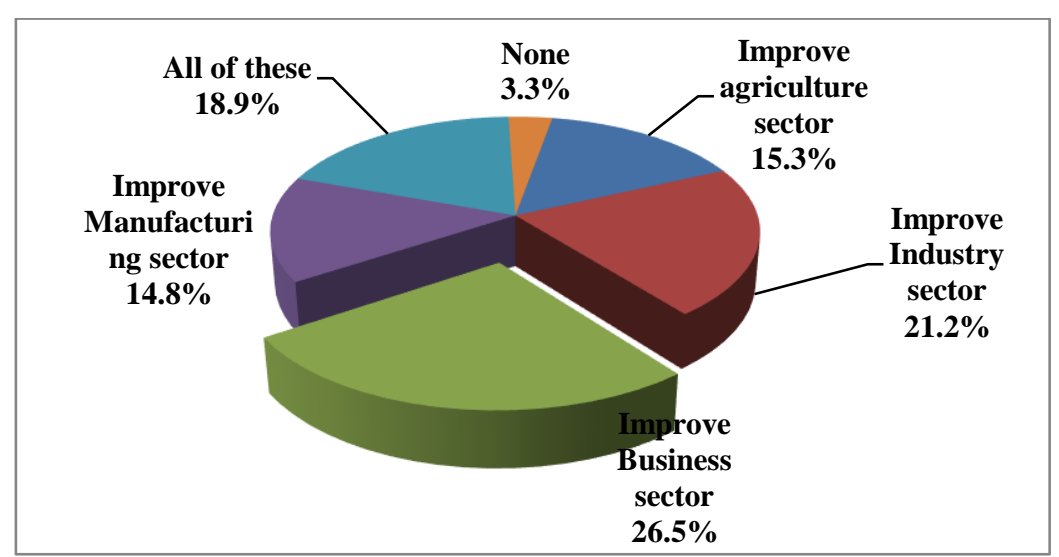

Figure 7. Information that CPEC will improve the different sectors

\section{Prospects of China from CPEC Project}

Physically factor of view Significant of CPEC import for China. Table 6 discusses that $19.0,18.4,22.8$ and $16.3 \%$ of the respondents had thought that addition of a volume of

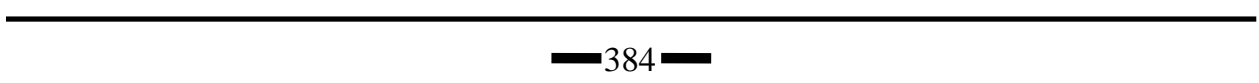


trade with Arab, African and European countries, equal development in China, Shorter route and save time and Provide a good way, whereas $19.6 \%$ of them noted that all above these discussed CPEC project is necessary of $\mathrm{F}$ and $3.0 \%$ of them did not know this opinion. Its geographical China location puts it on the main route between China Middle East and China-Central Asia. Because the Indian Ocean could be essential from the global economically point of view (Zweig, 2005).

Table 6: Respondent's information about why CPEC is necessary for China?

\begin{tabular}{|c|c|c|}
\hline Why is CPEC necessary for China? & Frequency & Percer \\
\hline Addition of volume of trade with Arab & 199 & 19.0 \\
\hline \multicolumn{3}{|l|}{ African and European countries } \\
\hline Equal Development China & 184 & 18.4 \\
\hline Shorter route and save time & 228 & 22.8 \\
\hline Provide a good way & 163 & 16.3 \\
\hline All of these & 30 & 3.0 \\
\hline Total & 1000 & 100.0 \\
\hline $\begin{array}{l}\text { All of these, } \\
\text { Provide a } \\
\text { good way, } \\
16.3 \%\end{array}$ & $\begin{array}{r}\text { Eq } \\
\text { Devel } \\
\text { in } \mathrm{C} \\
18\end{array}$ & $\begin{array}{l}\text { ion of } \\
\text { ne of } \\
\text { with } \\
\text { wfrican } \\
\text { id } \\
\text { pean } \\
\text { ries,... }\end{array}$ \\
\hline
\end{tabular}

Figure 8. Information about why CPEC necessary for China

\section{CPEC Project Provide the Link of the Road}

Table 7 reveals that $14 \%$ of the respondents had thought that a road links Gwadar port to Xingjian Uyghur Autonomous Region, while $23 \%$ of the selected community had thought that a road which links China to Pakistan, 38\% of them had observed that a road which links to the world, whereas $25 \%$ of the respondents had agreed all the opinions that CPEC 


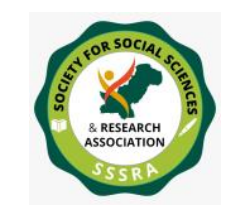

Pak. Journal of Int'L Affairs, Vol 4, Issue 4 (2021) $\quad$ Future Prospects of Pakistan China Relations ...

project is the link to any road ( $\mathrm{Li}, 2018)$. Xinjiang Uyghur Autonomous Region is officially assigned a "center region" of the BRI in light of the fact that it sits at the core of Central Asia's provincial vehicle networks. While because of CPEC, Pakistan gets connected with different nations and will turn into an exchange center. It very well may be a distinct advantage plan for Pakistan. With the advancement of Gwadar port, the development of boats and freight vessels could be very huge. Cost duties will produce numerous profit as various nations import and commodity their merchandise on this course (Wang, 2018). Another side it is viewed as that after the culmination of Gwadar port, Pakistan could be an exchange center point for the whole area because of the obligation free financial zone (Bhutta, 2015). Economists and strategic analysts believe that CPEC is a game-changer task that is no longer most effective for Pakistan and China but the whole region precisely and for the world in popular.

Table 7: Respondent's knowledge that the CPEC project is the link to the roads

\begin{tabular}{ccc}
\hline Response & Frequency & Percentage \\
\hline A road link Gwadar port to Xingjian region & 140 & 14 \\
A road that links China to Pakistan & 230 & 23 \\
A road which links to the world & 380 & 38 \\
All of these & 250 & 25 \\
Total & 1000 & 100.0 \\
\hline
\end{tabular}

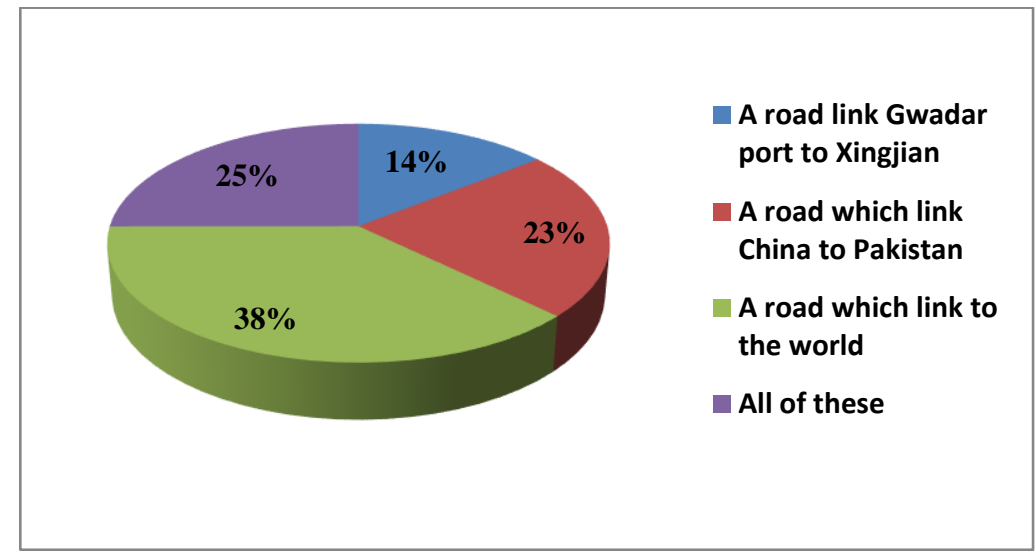

Figure 9. The knowledge that the CPEC project is the link to the roads

\section{Important Factor of the CPEC Project}




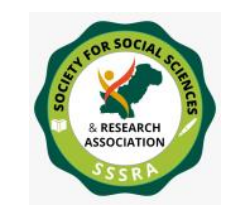

Pak. Journal of Int'L Affairs, Vol 4, Issue 4 (2021) $\quad$ Future Prospects of Pakistan China Relations ...

Table 8 indicates that $20.6 \%$ of the respondents reported that unemployment reduces; however, $21.2 \%$ of them told that poverty reduction in the country, $22.7 \%$ of the respondents said that equal development for investment, $17.6 \%$ of them expressed that living standard of the people, $15.8 \%$ of them observed that all above these discussed CPEC project important role to development in Pakistan and whereas $2.1 \%$ of them had no knowledge about this opinion. Additionally, Need will in like manner be given to changing specialized organizations and preparing with CPEC related exchanges and request of Special Economic Zones. The early gather projects under CPEC have made north of 75,000 direct positions and 200,000 associated positions for Pakistanis, while the midterm and long ventures under CPEC are ready to make in excess of 700,000 business valuable open doors in the nation. Moreover, Daily Times (2017) reported that under the CPEC project, special economic areas would be set up within the far off regions of Pakistan to be useful in poverty decrease, offer employment possibilities and play an important function in improving underdevelopment regions (Daily Times, 2017).

Table 8: Respondent's information about CPEC important role in social development in Pakistan

\begin{tabular}{ccc}
\hline Response & Frequency & Percentage \\
\hline Unemployment reduces & 206 & 20.6 \\
Poverty reduces & 212 & 21.2 \\
Equal development & 227 & 22.7 \\
The Living standard of the people & 176 & 17.6 \\
All of these & 158 & 15.8 \\
None & 21 & 2.1 \\
Total & 1000 & 100.0 \\
\hline
\end{tabular}

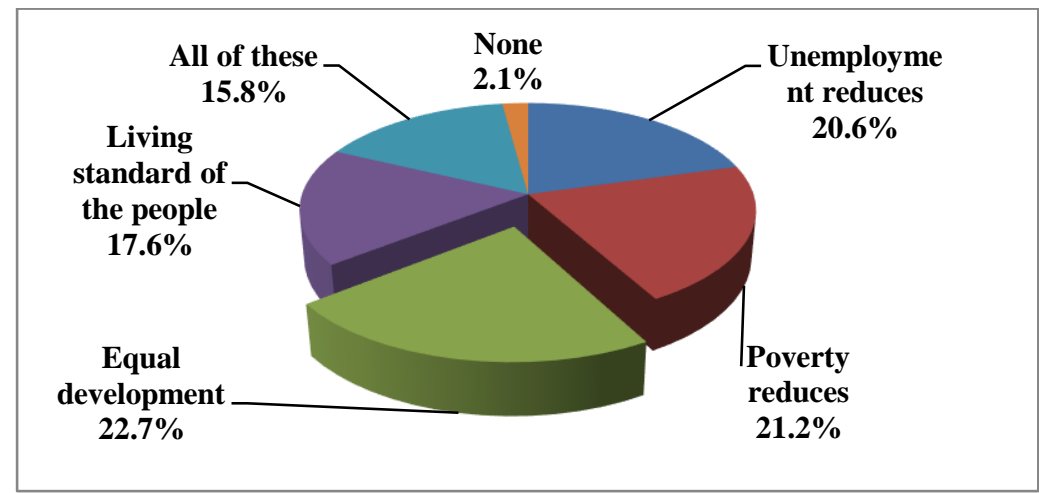

Figure 10. Information about CPEC value in social development in Pakistan

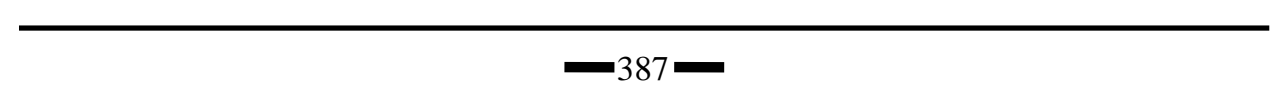




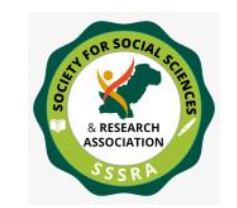

Pak. Journal of Int'L Affairs, Vol 4, Issue 4 (2021) Future Prospects of Pakistan China Relations ...

\section{CPEC Project Complete on Time}

Table 9 reveals that a great majority, $89 \%$ of the selected people had thought that the CPEC project was complete on time, while $5 \%$ of them said that the CPEC project was complete in time, whereas $6 \%$ of the respondents did not know about the CPEC project is complete in time. Coincidentally, for the biggest infrastructural project at any point snared inside the historical backdrop of Pakistan. A few activities are now in progress and expected to be done by utilizing as soon as 2018, with the transient time of CPEC to be finished by 2020, mid-term by 2025 and long haul by 2030 (Hilali, 2020).

Table 9: Respondent's knowledge about CPEC project is complete on time

\begin{tabular}{ccc}
\hline Response & Frequency & Percentage \\
\hline Yes & 890 & 89 \\
No & 50 & 5 \\
Don't Know & 60 & 6 \\
Total & 1000 & 100.0 \\
\hline
\end{tabular}

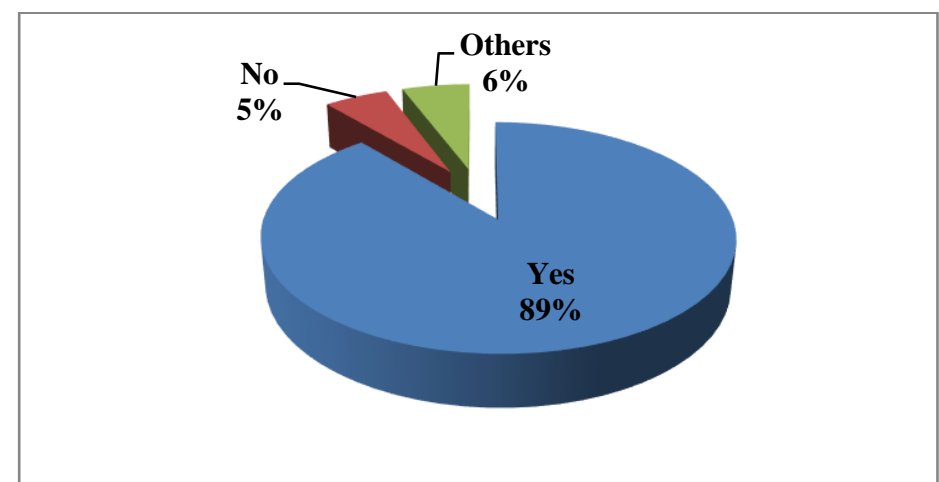

Figure 11. Knowledge about CPEC project complete on time

\section{The Perspective of CPEC Projects of the Education, Culture and Tourism in Pakistan}

The imminent of CPEC ventures of the instruction, culture and the travel industry in various fields of Pakistan will emphatically affect individuals later on, and accordingly the connection between the Pakistan and China will be even solid. Table 10 spread of the respondents had believed that under CPEC project great effect training trade program for the Pakistani understudies. Around 34.9\% of the respondents firmly concur, 52.7\% of them concurred that the CPEC project goodly affected the instruction of projects, though $11.8 \%$ of them had no assessment and $0.3 \%$ deviated, and $0.3 \%$ of the respondents emphatically 


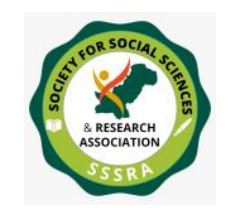

Pak. Journal of Int'L Affairs, Vol 4, Issue 4 (2021) Future Prospects of Pakistan China Relations ...

contradicted his viewpoint. As indicated by You Yi, Cultural Counselor of China in Pakistan, "Instructive trade programs among China and Pakistan have a fundamental capacity in reciprocal relations". However, 145 Pakistani understudies have as of late been granted grants to training in China (The Nation, 2017). Training is one of the fundamental parts of progress in practically every feeling of an economy (Gylfason, 2001). Around $26.3 \%$ of respondents emphatically concurred that acquainting the Chinese language with the schooling framework in colleges, and $37.4 \%$ of them concurred that the CPEC project assumes a significant part to present the Chinese language in various colleges, while $26.1 \%$ of them had no assessment, $8.2 \%$ differ and $2.0 \%$ of them firmly contradicted this assessment. Comparable, the two nations have set up different foundations to foster Chinese, English, and Urdu language for a special understudy trade program that has been made to advance sexual orientation and set up a grant for the understudies (Haider, 2019).

The relationship of the two nations concluded joint trade programs in various fields of schooling. In this assurance distinguishing that language is the significant obstruction in empowering social participation and individuals to-individuals joins among Pakistan and China, the two nations are going to joint lengths to set review places wherein the Chinese and Urdu dialects will educate. Close by $39.0 \%$ of respondents unequivocally concurred that schooling programs make Technology and development and $53.4 \%$ of them concurred that under the CPEC project instruction program make Technology and advancement in the nation; nonetheless, $6.6 \%$ of them had no assessment, $1.0 \%$ dissented, and $0.0 \%$ of them emphatically couldn't help contradicting this assessment. Social trades among Pakistan and China are both material and nonmaterial. They trade items, products, resources, contemplations, and qualities. With respect to the previous, China has conveyed fundamental foundation of transport and enterprises in Pakistan under the umbrella of CPEC. It has added new classifications of ages to Pakistanis such advancement impacts individuals (Toppa, 2018). Just $27.1 \%$ of respondents emphatically concurred that working on the way of life in Pakistan, and $22.8 \%$ of them concurred that under the CPEC project further develop culture framework; alternately, $27.4 \%$ of them had no assessment, $18.7 \%$ deviated, and $4.0 \%$ of them unequivocally couldn't help contradicting this assessment.

Beijing presently supports immense scope instructive and preparing software engineers transcendently designed for Pakistan washing to study or get hold of preparing in China. Various instructive and Cultural establishments focused on concentrating on Chinese culture, language, legislative issues, economy, and history are likewise set up in Pakistan (Wolf, 2021). Around $40.5 \%$ of respondents emphatically concurred that the venture would further develop the travel industry in Pakistan and 34.4\% of them concurred that under the CPEC project critical job in expanding the travel industry in Pakistan, while $13.8 \%$ of them had no assessment, $0.5 \%$ deviated, and $18.8 \%$ of them unequivocally contradicted this 


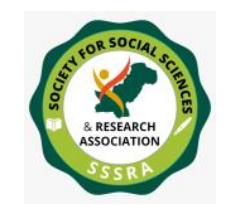

Pak. Journal of Int'L Affairs, Vol 4, Issue 4 (2021) Future Prospects of Pakistan China Relations ...

assessment. Also, China-Pak plays out an indispensable job in the improvement of social legacy in Pakistan. Along these lines, the endeavors of the two nations have amazingly worked on the way of life just as the travel industry. China-Pak is working on many undertakings like culture and the travel industry. In the reason, the assignment of the CPEC adventure can even rouse interests in grand spots and lodgings inside the area. Such advancement in the travel industry zone will, in an open door, benefit the general population of the area and the economy of Pakistan. By and by, the transport office is functional from Gilgit Baltistan to the Chinese boundary. Transportation is to be had for Kashgar and Urumqi from that point onwards. Air courses also associate the two urban communities, and 12 flights remove every day (Toor, 2017).

Pakistan gives loads of fascination inside the creating worldwide. The social and recorded legacy can be glaring in this antiquated area (Arshad, 2018). CPEC has fostered a focal point of examination because of its significant job in reasonable advancement objectives, financial improvement and expectations for everyday comforts. Just 35.0\% of respondents unequivocally concurred that CPEC positive effect on everyday citizens of life in Pakistan, and $47.1 \%$ of them concurred that under the CPEC, project positive effect on commoners of life in Pakistan, alternately, $14.5 \%$ of them had no assessment, $2.4 \%$ differ and $1.0 \%$ of them firmly contradicted this assessment. CPEC has turned into a solid focal point of exploration because of its significant job in reasonable advancement objectives, monetary improvement and expectations for everyday comforts (Awais, 2019).

A larger part, 56.4\%, of respondents emphatically concurred that the task would additionally reinforce the connection among China and Pakistan, and $41.2 \%$ of them concurred that the CPEC undertaking would more fortify the connection among China and Pakistan, while $2.4 \%$ of them had no assessment, $0.0 \%$ differ and $0.0 \%$ of them unequivocally contradicted this assessment. Pak-China relations are however old as these nations seem to be, and their relationship grew consistently in every space, including exchange and speculations (Ali, 2017). As portrayed in the Asian Development Bank study, "financial hallways join monetary specialists alongside a depicted geography". China-Pakistan monetary hall ought to convey tremendous financial opportunities for every Country, Pakistan and China. The undertaking of CPEC holds a speculation of billions of dollars and incorporates different opportunities for Pakistan. In any case, the viewpoint of CPEC projects in instruction, culture and the travel industry assume a significant part to give occupations open doors and neediness evacuation in Pakistan. Regardless, the viewpoint of CPEC projects in schooling, culture, and the travel industry assumes a significant part in giving positions open doors and neediness evacuation in Pakistan. Just 52.0\% of respondents unequivocally concurred that the CPEC project expands open positions in Pakistan, and $29.7 \%$ concurred that under the CPEC. Then 
again, $15.0 \%$ of them had no assessment, $1.9 \%$ dissented, and $1.4 \%$ unequivocally contradicted this assessment. Another side close by $4.7 .0 \%$ of respondents firmly concurred that the undertaking would assist with eliminating the neediness in Pakistan and $34.7 \%$ of them concurred that under the CPEC. However $16.0 \%$ of them had no assessment, $0.9 \%$ deviated, and $1.4 \%$ emphatically contradicted this assessment.

Table 10: Dissemination of the respondents had thought that impact of CPEC projects on Pakistan?

\begin{tabular}{|l|l|l|l|l|l|l|l|l|l|l|}
\hline Statements & \multicolumn{2}{|l|}{$\begin{array}{l}\text { Strongly } \\
\text { Disagree }\end{array}$} & \multicolumn{2}{l}{ Disagree } & \multicolumn{2}{l}{$\begin{array}{l}\text { No } \\
\text { Opinion }\end{array}$} & \multicolumn{2}{|l|}{ Agree } & \multicolumn{2}{l|}{$\begin{array}{l}\text { Strongly } \\
\text { Agree }\end{array}$} \\
\cline { 2 - 10 } & $F$ & $\%$ & $F$ & $\%$ & $F$ & $\%$ & $F$ & $\%$ & $F$ & $\%$ \\
\hline $\begin{array}{l}\text { Education } \\
\text { exchange with } \\
\text { scholarship } \\
\text { program for the } \\
\text { students }\end{array}$ & 3 & 0.3 & 3 & 0.3 & 118 & 11.8 & 527 & 52.7 & 349 & 34.9 \\
\hline $\begin{array}{l}\text { Introduce the } \\
\text { Chinese language } \\
\text { to education } \\
\text { system in } \\
\text { Universities }\end{array}$ & 20 & 2.0 & 82 & 8.2 & 261 & 26.1 & 374 & 37.4 & 263 & 26.3 \\
\hline $\begin{array}{l}\text { Education program } \\
\text { create Technology } \\
\text { and innovation }\end{array}$ & 0 & 0.0 & 10 & 1.0 & 66 & 6.6 & 534 & 53.4 & 390 & 39.0 \\
\hline $\begin{array}{l}\text { Improve the } \\
\text { culture in Pakistan }\end{array}$ & 40 & 4.0 & 187 & 18.7 & 274 & 27.4 & 228 & 22.8 & 271 & 27.1 \\
\hline $\begin{array}{l}\text { CPEC positive } \\
\text { impact of common } \\
\text { people of life in } \\
\text { Pakistan }\end{array}$ & 10 & 1.0 & 24 & 2.4 & 145 & 14.5 & 471 & 47.1 & 350 & 35.0 \\
\hline $\begin{array}{l}\text { CPEC project } \\
\text { increase job } \\
\text { opportunities in } \\
\text { Pakistan }\end{array}$ & 14 & 1.4 & 19 & 1.9 & 150 & 15.0 & 297 & 29.7 & 520 & 52.0 \\
\hline $\begin{array}{l}\text { The project will } \\
\text { help to remove the } \\
\text { poverty in Pakistan }\end{array}$ & 14 & 1.4 & 9 & 0.9 & 160 & 16.0 & 347 & 34.7 & 470 & 47.0 \\
\hline $\begin{array}{l}\text { The project will } \\
\text { further strengthen } \\
\text { the relation } \\
\text { between China and } \\
\text { Pakistan }\end{array}$ & 0 & 0.0 & 0 & 0.0 & 24 & 2.4 & 412 & 41.2 & 564 & 56.4 \\
\hline $\begin{array}{l}\text { The project will } \\
\text { improve tourism in } \\
\text { Pakistan }\end{array}$ & 188 & 18. & 5 & 0.5 & 138 & 13.8 & 344 & 34.4 & 405 & 40.5 \\
\hline
\end{tabular}


$\underline{\text { Pak. Journal of Int'L Affairs, Vol 4, Issue } 4 \text { (2021) Future Prospects of Pakistan China Relations ... }}$

A total of 1000 respondents had thought about the impact of CPEC projects in Pakistan on different fields.

\section{Multivariate Analysis}

\section{Binary Logistic Model Summary}

The calculated model was utilized to concentrate on the CPEC information and results; the Cox and Snell R Square worth was .045. The value of Cox and Snell R Square communicates that a $45 \%$ assortment in a model can be explained by the given elements, as various elements portray the rest of the assortments. While the value of Nagelkerke $\mathrm{R}$ Square was $.091 \%$, which states that $91 \%$ of varieties in the given model are legitimized because of given factors, though different factors as Table 11 can clarify the remainder of all progressions in the model introduces the model summary Binary Logistic Model.

Table 11: Model Summary

\begin{tabular}{|c|c|c|}
\hline $\begin{array}{c}-2 \text { Log } \\
\text { likelihood }\end{array}$ & $\begin{array}{c}\text { Cox \& Snell } \\
\text { R Square }\end{array}$ & $\begin{array}{c}\text { Naglkerke } \\
\text { R Square }\end{array}$ \\
\hline $630.312^{\mathrm{a}}$ & .045 & .091 \\
\hline
\end{tabular}

In our investigation, the Hosmer and Lemeshow test yielded an $X^{2} 5.103$ of $(p=0.78)$, which was highly imperative as Table 12 displays the Hosmer and Lemeshow test.

Table 12: Hosmer and Lemeshow Test

\begin{tabular}{|c|c|c|}
\hline Chi-square & Df & Significance \\
\hline 5.103 & 2 & 0.78 \\
\hline
\end{tabular}

According to the two judgments of those 9.6\% (1000/96) respondents that had no information about the CPEC project will progress. At the same time, $91.4 \%$ has fully expected that CPEC will progress in future. Table 13 explains the classifications of the CPEC project and its analysts using logistics regression observed and predicted beliefs.

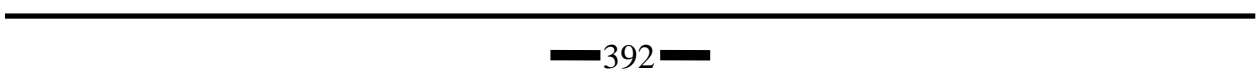


Table 13: Classification Table

\begin{tabular}{|c|c|c|c|}
\hline \multirow{3}{*}{ Observed } & \multicolumn{3}{|c|}{ Predicted } \\
\hline & \multicolumn{2}{|c|}{ CPEC } & \multirow{2}{*}{$\begin{array}{l}\text { Percentage } \\
\text { Correct }\end{array}$} \\
\hline & 1 & 2 & \\
\hline Step 1 CPEC 1 & 890 & 3 & 99.7 \\
\hline 2 & 92 & 14 & 13.2 \\
\hline Overall Percentage & & & 90.5 \\
\hline
\end{tabular}

The cut value is .500 .

Table 14: The CPEC project analysts using logistics regression

\begin{tabular}{|c|c|c|c|c|}
\hline & Coefficients & Wald & P-value & $\begin{array}{c}\text { Odds } \\
\text { Ratio }\end{array}$ \\
\hline Improve Economic & $.584^{*}$ & 4.398 & .036 & 1.793 \\
\hline $\begin{array}{c}\text { Improve Social } \\
\text { Development }\end{array}$ & $1.158^{* *}$ & 13.448 & .000 & 3.185 \\
\hline $\begin{array}{c}\text { Unemployment and } \\
\text { Poverty }\end{array}$ & $.160^{\mathrm{NS}}$ & .222 & .637 & 1.173 \\
\hline $\begin{array}{c}\text { Role of the } \\
\text { Education }\end{array}$ & $.702^{*}$ & 5.228 & .022 & 2.018 \\
\hline Constant & $-3.262^{* *}$ & 60.08 & .000 & .038 \\
\hline
\end{tabular}

Note: NS=non-significant, ${ }^{*}$ significant $(5 \%),{ }^{* *}=$ highly-significant $(1 \%)$

Naglkerke R Square: .091

-2 Log likelihood $=630.312^{\mathrm{a}}$

Hosmer and Lemeshow Test $:($ chi-square value $=5.103$, p-value $=0.78)$

Model of the CPEC:

$$
=-3.262+584 \mathbf{I E}+1.158 \mathbf{I S D}+160 \mathbf{U P}+702 \mathbf{R E}
$$

Where $\mathrm{p}=$ prospect of potential key points which impact of China Pakistan Economic Corridor (CPEC) project.

Improve Economic:

The above table 14 shows that the CPEC project has an essential role in improving economics. From the odds ratio of improving Economic 1.793, it is clear that respondents' 


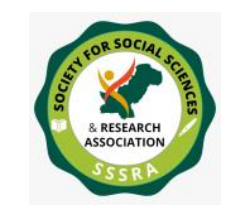

Pak. Journal of Int'L Affairs, Vol 4, Issue 4 (2021) $\quad$ Future Prospects of Pakistan China Relations ...

thinking that Improve Economic has increased, and the respondents have a good opinion about the CPEC project.

Improve Social Development:

The above table 14 displays that the CPEC project has an essential role in improving social development. From the odds ratio of improving social development 3.185, it is clear that respondents' thinking that improves social development has increased, and the respondents have a good impression about the CPEC project.

Role of the Education \&Unemployment and Poverty:

CPEC project also has an essential role in the Education \& Unemployment and Poverty Reduction. About the CPEC project, the respondents have a good impression that the project will positively affect the future. While the p-value appearances a significant relationship between the variables.

\section{Conclusion}

The Chinese and Pakistani governments dream of building the CPEC project, constructing the energy sector, road, railways lines, transportation infrastructure, Gwadar port and social-economic development. However, the CPEC is the project umbrella of OBOR, which is a basic objective to generate Pakistan's multi-dimensional groundwork and economy. Nowadays, China-Pakistan Economic Corridor is a hot topic for China and Pakistan as a substitute; it is essential in the world's eyes. The history of Pakistan $\$ 62$ billion will be spent on different projects of CPEC as the biggest benefit of the CPEC project will be Pakistan's economic strength and positive effect on Pakistani GDP growth. This project will provide business prospects, industrialized, thousands of new job employment opportunities to the people of Pakistan. So unemployment and poverty determination be reduced in the country. Moreover, the project of CPEC education and culture exchange program will have good effects people of Pakistan. On another side, under the CPEC project through Gwadar port to Xinjiang Uyghur Autonomous Region. Shortly, the Gwadar seaport will increase its importance because it becomes a trade hub in the future.

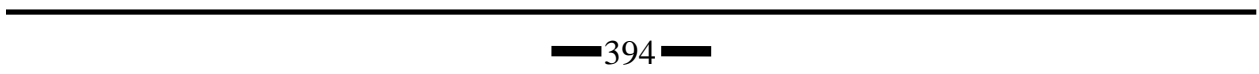




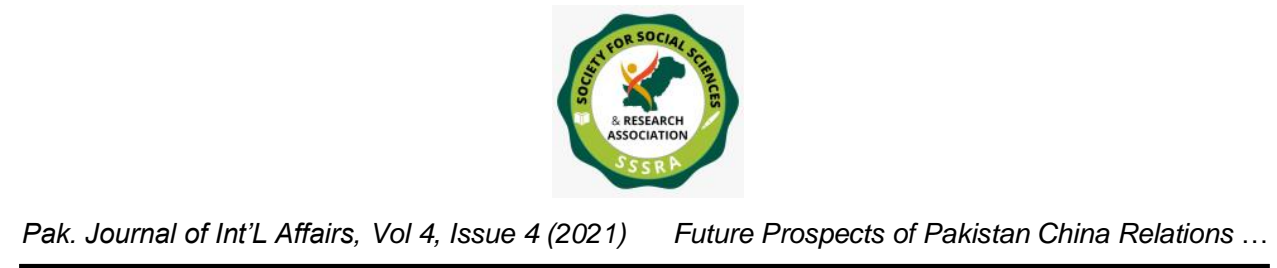

\section{References}

Ibrar, M., Mi, J., Mumtaz, M., Rafiq, M., \& Buriro, N. H. (2018). The Importance of ChinaPakistan Economic Corridor from Regional Development Perspective. 31st International Business Information Management Association (IBIMA 2018), Milan, Italy.

Abid, M., \& Ashfaq, A. (2015). CPEC: Challenges and opportunities for Pakistan. Journal of Pakistan Vision, 16(2), 142-169.

Ali, G. (2015). China and Pakistan prepare to establish economic corridor. Central AsiaCaucasus Analyst, 15.

Bhola, P. L. (1986). Pakistan-China relations: Search for politico-strategic relationship. South Asia Books.

Bhoothalingam, R. (2016). The Silk Road as a global brand. China Report, 52(1), 45-52.

Das, K. C. (2017). The making of one belt, one road and dilemmas in South Asia. China Report, 53(2), 125-142.

Jinping, X. (2017, October). Secure a decisive victory in building a moderately prosperous society in all respects and strive for the great success of socialism with Chinese characteristics for a new era. In delivered at the 19th National Congress of the Communist Party of China (Vol. 18).

Kalathil, S. (2017). China's Eurasian Century? Political and Strategic Implications of the Belt and Road Initiative by Nadège Rolland. Journal of Democracy, 28(4), 170-174.

Liping, X. (2015). The Development of the "One Belt and One Road" and its Impact on ChinaUS Relations. Chinese People's Association for Peace and Disarmament. Beijing, China.

Malik, H. Y. (2012). Strategic Importance of Gwadar Port. Journal of Political Studies, 19(2).

Markey, D. S., \& West, J. (2016). Behind China's gambit in Pakistan. Council on Foreign Relations, 5(1), 31.

Masood, T. (2015). Pakistan's unique relations with China. The Express Tribune. 


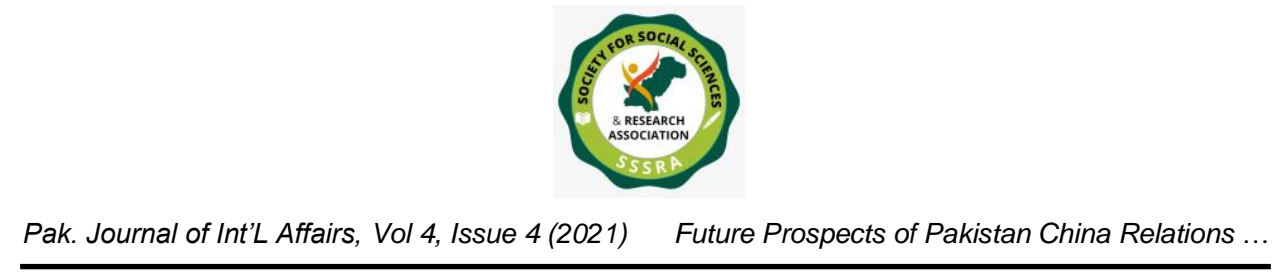

Ramasamy, B., Yeung, M., Utoktham, C., \& Duval, Y. (2017). Trade and trade facilitation along the Belt and Road Initiative corridors.

Sarker, M. N. I., Hossin, M. A., Yin, X., \& Sarkar, M. K. (2018). One belt one road initiative of China: implication for future of global development. Modern Economy, 9(4), 623-638.

Uberoi, P. (2016). Problems and prospects of the BCIM economic corridor. China Report, 52(1), $19-44$.

Ul Hassan, Y. (2020). China-pakistan economic corridor (CPEC) and questions on pakistan's economic stability. Strategic Analysis, 44(2), 137-152.

Vertzberger, Y. (1983). The political economy of Sino-Pakistani relations: Trade and aid 196382. Asian Survey, 23(5), 637-652.

Achakzai, J. (2018). 70,000 Employed Under CPEC, $0.7 \mathrm{~m}$ to Get More Jobs. The News International, 4.

Ahmad, R., \& Mi, H. (2017). Arts and social sciences journal. Arts and Social Sciences Journal, 8, 2.

Akber, A. L. I. (2015). China Pakistan Economic Corridor (CPEC): Prospects and challenges for regional integeration. International Journal of Social Sciences and Humanity Studies, 7(1), $1-15$.

Alexandrova, A. (2009). When analytic narratives explain. Journal of the Philosophy of History, 3(1), 1-24.

Bhattacharjee, D. (2015). China Pakistan economic corridor. Available at SSRN 2608927.

Kalim, R., Faiz, I., \& Arshed, N. (2019). Investor Confidence and Asymmetric Effects of Terrorism-A case of Pakistan. Journal Transition Studies Review, 26(2), 113-124.

Khalid, A., \& Khalid, S. (2015). Relationship between organizational commitments, employee engagement and career satisfaction a case of university of Gujrat, Pakistan. Journal of South Asian Studies, 3(3), 323-330.

Mughal, K. (2016). Energy sector projects under CPEC. Retrieved May, 15, 2017. 


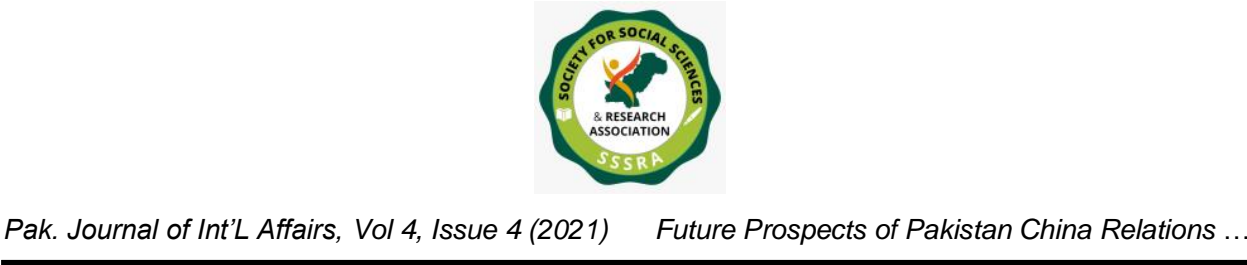

Naz, L., Ali, A., \& Fatima, A. (2018). International competitiveness and ex-ante treatment effects of CPEC on household welfare in Pakistan. International Journal of Development Issues.

Rafiq, A. (2016, December). CPEC \& related projects: CPEC projects. In Proceedings of the International Academic Symposium on China-Pakistan Economic Corridor, Beijing, China (Vol. 5).

Rahman, K. (2018). China-South Asia Communications under BRI: The CPEC Model. Policy Perspectives: The Journal of the Institute of Policy Studies, 15(1), 63-79.

Ramay, S. A. (2016). China Pakistan economic corridor: A Chinese dream being materialized through Pakistan. Sustain. Dev. policy Inst.,

Raza, S. I. (2013). China given contract to operate Gwadar port. Dawn.

Siddiqui, S. (2017). CPEC investment pushed from $\$ 55$ b to $\$ 62$ b. The Express Tribune, April 12.

Stevens, A. (2015). Pakistan lands \$46 billion investment from China. CNN Money, 20.

Xiguang, L., \& Lizhou, S. (2015). The strategic value and security situation of the China-Pakistan economic corridor. Frontiers, 12, 005.

Yun, Y. (2015). China-Pakistan economic corridor: a risk analysis. South Asian Studies, 2, 35-45.

Akbar, M., \& Ahsan, A. K. B. A. R. (2015). An empirical analysis of foreign direct investment in Pakistan. Studies in Business and Economics, (10).

Bhutta, Z. (2015). India bid to halt Pakistan projects fails. The express tribune, 31 .

Daily Times, (2017). CPEC to Bring about the Social-economic Revolution in the Region. Daily Times, avaiable at: https://dailytimes.com.pk/114471/cpec-to-bring-about-socio-economicrevotution-in-region-pu-vc/."

Hilali, A. Z. (2020). China-Pakistan Economic Corridor (CPEC): A MultiDimensional Plan 20172030 and Its Characteristics. South Asian Studies, 34(2). 


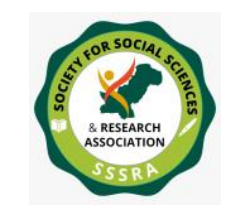

Pak. Journal of Int'L Affairs, Vol 4, Issue 4 (2021) $\quad$ Future Prospects of Pakistan China Relations ...

Li, K. X., Jin, M., Qi, G., Shi, W., \& Ng, A. K. (2018). Logistics as a driving force for development under the belt and road initiative-the Chinese model for developing countries. Transport Reviews, 38(4), 457-478.

The Nation (2017). 'Sino-Pak educational exchange programs must for cordial ties'. The Nation Avalable at: http://nation.com.pk/islamabad/17-Aug-2017/sino-pak-educationalexchangeprogrammes-must-for-cordial-ties."

Wang, J., Yao and Nie, (2018) Is China colonizing Pakistan?, Daily Times, available at: https://dailytimes.com.pk/241861/is-china-really-colonising-pakistan/

Zweig, D., \& Jianhai, B. (2005). China's global hunt for energy. Foreign affairs, 25-38.

Gylfason, T. (2001). Natural resources, education, and economic development. European economic review, 45(4-6), 847-859.

Haidar, S., \& Fang, F. (2019). English language in education and globalization: A comparative analysis of the role of English in Pakistan and China. Asia Pacific Journal of Education, 39(2), 165-176.

Toppa, S. (2018). Why Young Pakistanis Are Learning Chinese. The Atlantic, 14.

Wolf, S. O. (2021). China-Pakistan Economic Corridor of the Belt and Road Initiative. Springer.

Ali, G. (2017). China-Pakistan relations: a historical analysis. Oxford University Press

Arshad, M. I., Iqbal, M. A., \& Shahbaz, M. (2018). Pakistan tourism industry and challenges: a review. Asia Pacific Journal of Tourism Research, 23(2), 121-132.

Awais, M., Samin, T., Gulzar, M. A., \& Hwang, J. (2019). The sustainable development of the China Pakistan economic corridor: synergy among economic, social, and environmental sustainability. Sustainability, 11(24), 7044.

Toor, M. R. (2017). An assessment of China-Pakistan Economic Corridor: Threats, prospects and implications. International Affairs and Global Strategy, 56.

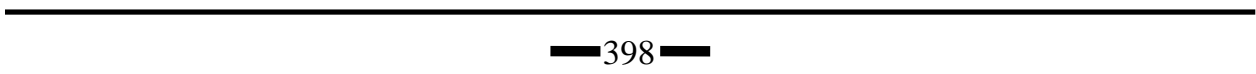

